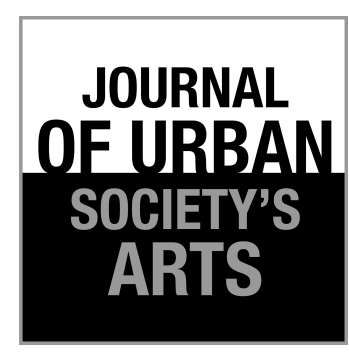

Volume 3 Nomor 2, Oktober 2016: 102-109

\title{
Fotografi Jalanan: Membingkai Kota dalam Cerita
}

Kusrini

Jurusan Fotografi, Fakultas Seni Media Rekam

Institut Seni Indonesia Yogyakarta

Jl. Parangtritis Km. 6,5 Sewon Yogyakarta

Tlp.085799939542,E-mail: kusrini.campus@gmail.com

\begin{abstract}
ABSTRAK
Fotografi jalanan (street photography) menjadi sarana bagi fotografer Erik Prasetya untuk menggambarkan kota Jakarta secara visual dalam buku foto Jakarta: Estetika Banal. Di dalamnya terdapat hasil kerja fotografi selama sekitar 20 tahun yang berisi cerita tentang Jakarta. Foto-foto tersebut dicermati secara keseluruhan untuk mengetahui gambaran umum tentang Jakarta yang diusung oleh fotografer. Fotofoto tersebut dipilih sesuai dengan deskripsi umum dan dibahas lebih lanjut untuk mendapatkan cerita tentang Jakarta pada 1990-2000'an. Dalam foto-foto tersebut, Jakarta merupakan kota dengan masyarakat yang dinamis. Jalanan tidak pernah sepi dan tidak tidur meskipun di waktu malam. Bangunan, transportasi, para pekerja, mobilitas yang tinggi, menjadi bagian dari visual Jakarta, yang sekaligus menceritakan masih adanya kesenjangan ekonomi dan sosial masyarakatnya. Di dalamnya ternyata masih juga terdapat tawa dan kegembiraan. Semangat bertahan hidup di ibukota menjadi bagian yang tidak terpisahkan dari cerita tentang Jakarta. Keindahan foto terlihat dari imaji yang ditampilkan mengeksplorasi teknik manual yang disesuaikan dengan kondisi dan situasi serta cerita yang hendak disampaikan. Keindahan lain dalam fotografi jalanan karya Erik Prasetya ini terdapat dari cerita visual yang tersaji. Fotografi jalanan tidak sekadar cerita tentang jalanan secara fisik, namun juga cerita tentang masyarakat di sepanjang jalan serta perjalanan kehidupan yang dilalui fotografer.
\end{abstract}

Kata kunci: Erik Prasetya, fotografi jalanan, Jakarta

\begin{abstract}
Street Photography: Framing City in Stories. Erik Prasetya is photographer who uses street photography (fotografi jalanan) to narrate visually Jakarta in a photo book titled Jakarta: Estetika Banal. There are photos of his work for 20 years about Jakarta. The photos are examined as a whole to know the general idea of Jakarta carried by the photographer. They are selected to get the general description and finally are studied further to get stories about Jakarta in late 1990-2000. In these photos, Jakarta is a city with a dynamic society. The streets are never quiet and do not sleep at night though. Building, transportation, greater mobility of workers, become parts of Jakarta visually, which also tell the persistence of economic and social discrepancy in society. However, there are laughter and exhilaration that we can find. The spirit to survive in the capital becomes an integral part of the story of Jakarta. The beauty of the photos came from the images are displayed exploring manual techniques adapted to the conditions and situations, and stories that would be submitted. Another beauty of street photography works by Erik Prasetya is that there is a visual story presented. Street photography is not just a story about the streets physically, but also stories of people found along them as well as the journey of life experienced by the photographer. Keywords: Erik Prasetya, street photography, Jakarta
\end{abstract}




\section{Pendahuluan}

Fotografi jalanan (street photography) merupakan salah satu genre fotografi yang membidik kehidupan masyarakat urban yang berada di jalan dan sekitarnya dengan memotret apa adanya tanpa mengarahkan. Fotografi jalanan memotret orang-orang dengan menghadirkan skyscrapers maupun cityscape yang menghadirkan representasi wajah sebuah kota (Abdi 2011). Perkembangan fotografi jalanan tidak lepas dari sejarah fotografi yang lahir pada akhir abad ke-18 dan awal abad ke-19, pada masa pertumbuhan kota dan industri, yang dibangkitkan oleh kehebatan kesusastraan dan seni dalam merespons meningkatnya pengaruh daerah perkotaan khususnya London, Paris, dan New York. Pada abad ke-19 tersebut, kota menjadi sentral gambar untuk kamera dalam berbagai bentuk pendekatannnya (Clarke 1997).

Salah satu pendekatan fotografi yang dianggap sebagai bentuk rekaman tentang kota yang apa adanya, adalah karya Berenice Abbott yang berjudul "Columbus Circle". Dalam foto ini, Abbott, yang merupakan orang kepercayaan Eugene Atget, yang tidak membatasi kamera atau fokus lensa pada makna tertentu. Abbott menggunakan kamera dengan bermacam cara serta seplural mungkin (Clarke 1997). Abbott menggunakan kebenarannya sendiri dalam menggambarkan ruang kota New York pada masa itu. Abbott bercerita tentang ikon dari Amerika dan foto itu membuat kota seperti sebuah teks atau naskah utama yang menjadi pusat perhatian. Selain Abbott, tokoh lain adalah Eugene Atget. Menurut Clarke (1997), karya Atget lebih berbicara tentang psikologi, bukan pemetaan fisik dari kota Paris. Meskipun foto-fotonya terlihat kosong tanpa sosok, Atget merunut waktu dan ritme dari rutinitas kehidupan dan dasar kebutuhan manusia yang membuat tanda di permukaan kota: tanda-tanda dari tempat tinggal yang sebenarnya. Atget terus mencari rahasia dari kota, dan bermaksud memasukkan hal itu ke dalam fotonya, hingga suatu saat Atget mendeklarasikan identitas kota, seolah-olah ada dalam sebuah cerita detektif.

Salah satu foto karya Atget berjudul "Storefront, Avenue des Gobelins" (1925), menggambarkan tentang manekin di sebuah etalase toko. Refleksi gedung serta pepohonan terpantul pada kaca di depan etalase (http://www.getty. edu/diakses pada Kamis, 14 Januari 2016, pukul 23.14 WIB). Selain Atget, tokoh lain yang dikenal dengan gaya fotografi jalanan adalah Henry Cartier Bresson. Konsep tentang the dececive moment menjadikannya dia sebagai Bapak Foto Jurnalisme Modern (http://www.magnumphotos.com/diakses pada Kamis, 14 Januari 2016, pukul 23.13 WIB). Terdapat juga Garry Winogrand, fotografer New York. Winogrand menggambarkan kehidupan di New York melalui karya-karya fotonya dengan cara inovatif dan berbeda. Winogrand pun dianggap sebagai fotografer yang berhasil menetapkan cara baru dalam fotografi yaitu street photography. Selama tahun 1950-1960, Winogrand menyusuri trotoar sepanjang New York. Melalui persenjataan kamera dan puluhan gulungan rol film, Winogrand memotret kehidupan sehari-hari penduduk kota (http://www.telegraph.co.uk/diakses pada Kamis, 14 Januari 2016, pukul 22.47 WIB).

Contoh-contoh foto dari fotografer pendahulu street photography tersebut tidak sekadar memperlihatkan gedung-gedung besar yang identik berada di daerah perkotaan. Dalam foto-foto tersebut juga terdapat ikon sebuah kota dan orangorang dengan atributnya sendiri yang secara umum dapat dilihat bagaimana tingkat mode masyarakat tersebut. Terdapat banyak orang yang lalu-lalang di sebuah tempat, aksi massa, toko pakaian dengan pajangan etalase kaca yang biasanya ditemui di toko yang menjual dalam skala besar. Genre foto

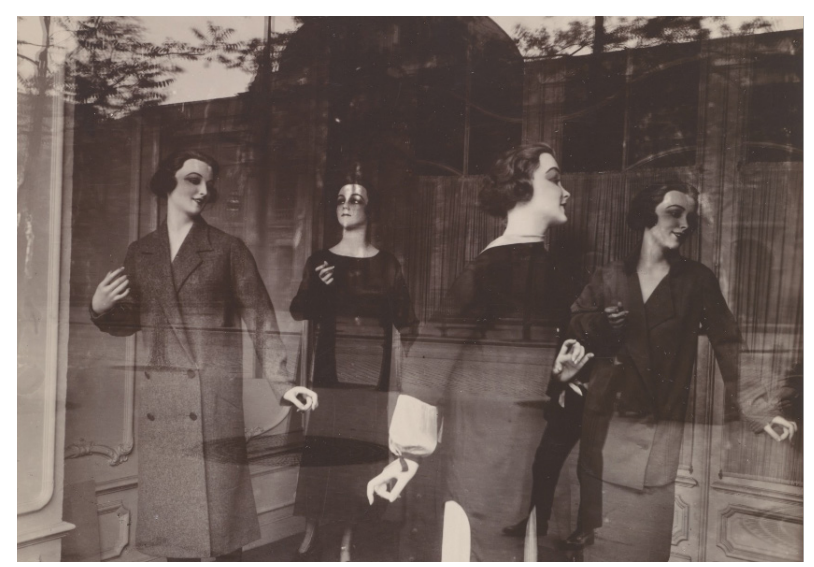

Gambar 1. "Storefront, avenue des Gobelins", 1925, karya Eugene Atget. (Sumber: http://www.getty.edu/ diakses pada Kamis, 14 Januari 2016, pukul 23.14 WIB). 
ini memang lebih menekankan pada dinamika kehidupan masyarakat urban daripada persoalan sosial sehingga keragaman objek dapat terlihat dari imaji-imaji yang tercipta (Abdi 2011).

Soedjono (2006) dalam buku Pot-Pourri Fotografi menyebutkan jika penamaan istilah 'fotografi jalanan' lebih pada istilah yang mengacu pada objek fotografi yang ada. Dalam hal ini maka dari sisi sejarah fotografi ditemukan dan berkembang pada abad XIX dengan mengabadikan berbagai objek yang ada di dalam kota, serta konteks 'jalanan' yang dimaksud juga berorientasi pada lokasi setiap objek 'jalanan' di dalam kota. Kota yang dimaksud adalah 'wadah' yang berisikan berbagai aspek kehidupan manusia urban dengan segala interaksinya dengan lingkungan tempat seseorang berada dalam suatu masyarakat dan pada waktu tertentu. Dapat dikatakan lebih lanjut bahwa pengambilan objek-objek 'jalanan' merupakan upaya untuk mendokumentasikan peristiwa, kejadian, objek-objek keseharian yang terdapat di daerah urban dengan berbagai masalah kehidupan sosialnya.

Berdasar atas sisi keruangan, 'jalanan’ merupakan ruang publik yang memungkinkan terjadinya berbagai interaksi sosial dari berbagai tataran sosial masyarakat (Soedjono, 2015). Ruang publik ini dapat disikapi sebagai ruang kota dengan ragam kontras sosial antara tampilan potret si miskin dan kaya dengan berbagai aspek yang melingkupinya, antara besar dan kecil, antara siang dan malam, antara luas dan sempit, tinggi

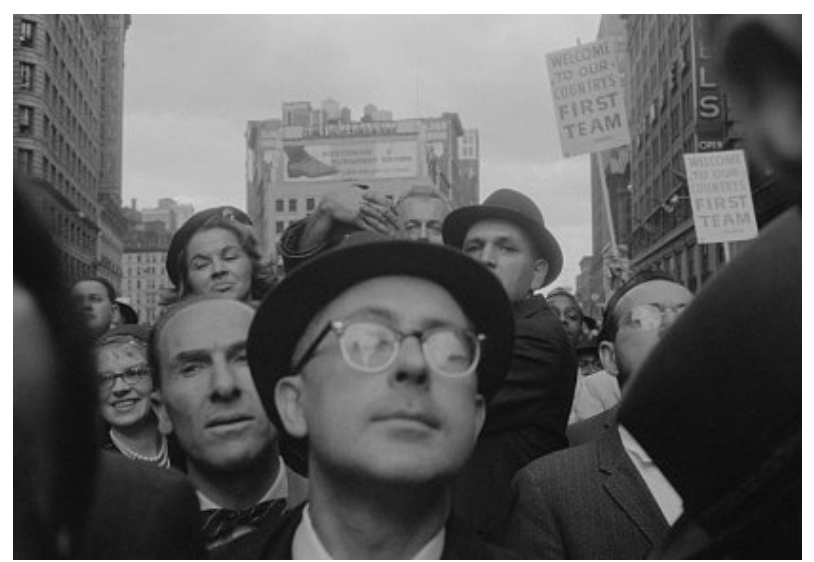

Gambar 2. Richard Nixon Campaign Rally, 1960, karya Garry Winogrand. (Sumber: http://www.telegraph. co.uk/diakses pada Kamis, 14 Januari 2016, pukul 22.47 WIB) dan rendah, kuat dan lemah serta berbagai kontras fisik maupun psikis antara benda hidup dan mati. Objek merupakan kehidupan yang kompleks, dapat berupa manusia, jajaran gedung-gedung dengan keunikan arsitektur, poster yang terkoyak, rambu-rambu lalulintas, kendaraan yang lalu lalang maupun parkir di pinggir jalan, tempat sampah, grafiti berbagai corak di dinding-dinding. Objekobjek tersebut mungkin memiliki keunikan yang tersembunyi di balik nilai "ordinary" kehadirannya yang sering tidak mendapat perhatian cukup. Objek-objek tersebut apabila dicermati, diteliti dan dapat diabadikan, ternyata akan memiliki nilai humanitas yang tidak terduga.

Di Indonesia, salah seorang fotografer yang dianggap sebagai pelopor fotografi jalanan adalah Erik Prasetya. Perjalanan Erik Prasetya sebagai fotografer pada awalnya tidak mulus. Erik pernah berganti-ganti pekerjaan, dari pekerja tambang hingga wartawan tulis. Erik kemudian teringat akan hobinya memotret, dia berpikir tentang pekerjaan yang menyenangkan. Erik pun mulai bekerja di bidang fotografi di Majalah Tempo dan membantu beberapa juru foto senior seperti Ed Zoelverdi dan Sebastiáo Salgado. Sejak menjadi fotografer, Erik memotret banyak hal tentang kehidupan Jakarta, kota tempatnya tinggal. Salah satu buku foto karyanya, Jakarta: Estetika Banal, menjadi salah satu buku "pegangan" untuk street photography di Indonesia (http://inet.detik.com/ diakses pada Kamis, 14 Januari 2016, pukul 23.18 WIB).

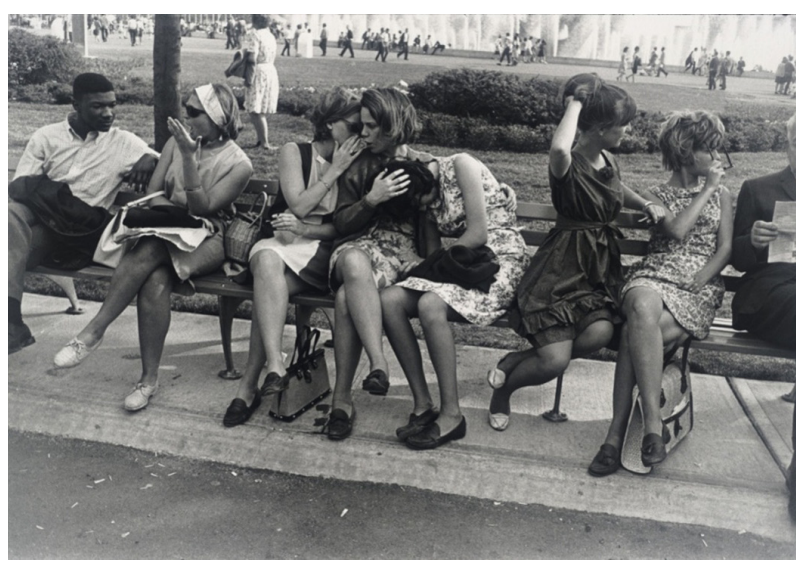

Gambar 3. New York World's Fair, 1964, karya Garry Winogrand/Courtesy Fraenkel Gallery, San Francisco (Sumber: http://www.theguardian.com/ diakses pada Minggu, 17 Januari 2016, pukul 15.59 WIB) 
Foto-foto dalam buku ini merupakan proyek panjang Erik Prasetya selama 20 tahun tinggal di Jakarta. Dalam buku bagian isi terdapat 120 foto tersaji yang dikelompokkan menjadi 10 bagian, dengan masing-masing dibatasi oleh penggalan puisi. Puisi-puisi yang terdapat dalam buku ini merupakan karya Goenawan Mohamad, Chairil Anwar, Zen Hae, Joko Pinurbo, dan Wiji Thukul. Puisi-puisi tersebut beberapa di antaranya secara lengkap terdapat di bagian belakang buku. Pada buku bagian depan terdapat catatan kuratorial dengan disertai foto-foto. Buku ini mengambil judul tentang estetika banal karena Erik mencoba mencari sisi estetika dari kondisi fisik kota Jakarta yang cenderung banal-membosankan, biasa, tak memiliki keistimewaan (Prasetya 2011). Erik menyatakan, foto-foto di dalam buku ini merupakan sebuah ikhtiar untuk menemukan estetika yang dituntut Jakarta untuk memahami dirinya (Prasetya 2011). Tulisan ini untuk mengetahui cerita tentang Jakarta pada tahun 1990-2000'an oleh Erik Prasetya melalui fotografi jalanan, baik yang tertampak dalam imaji maupun dalam sebalik pesan visual.

\section{Imaji Visual Urban Jakarta}

Erik Prasetya, fotografer yang tinggal di Jakarta, sehari-hari bergelut dengan kehidupan Jakarta mendokumentasikan kehidupan Jakarta dalam bentuk karya foto. Erik melakukan proyek pemotretan Jakarta ini selama 20 tahun. Pendekatan yang digunakan tidak biasa, karena menurut Erik, Jakarta adalah kota yang tidak cantik

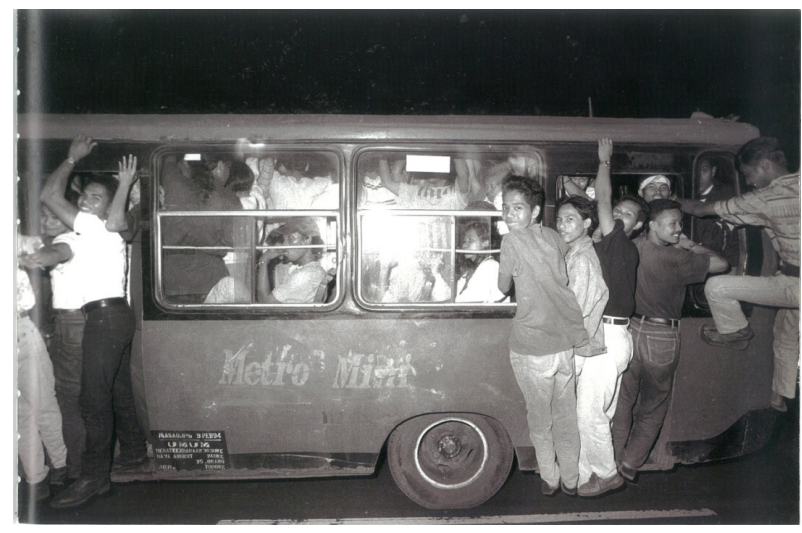

Gambar 4. Jalan Sudirman, 1993

(Sumber: Prasetya 2011)
(Prasetya 2011). Fotografi jalanan dipilih sebagai media yang digunakan untuk mengungkapkan Jakarta pada masa 1990-2000'an karena dianggap memiliki tuntutan penyingkapan realitas. Beberapa foto yang dibahas dalam tulisan ini dipilih sesuai tujuan untuk melihat masyarakat urban Jakarta dalam potret fotografi jalanan. Foto-foto tersebut dicermati terlebih dulu untuk mengetahui gambaran umum tentang Jakarta secara visual. Setelah itu ditentukan foto-foto yang sesuai tujuan penulisan untuk dibahas lebih lanjut.

Foto-foto karya Erik Prasetya tentang Jakarta lebih banyak bercerita tentang masyarakat urban (perkotaan) dan aktivitasnya. Gedung-gedung adalah bagian dari masyarakat itu sendiri, bukan menjadi bagian utama dari masyarakat. Salah satu foto yang dapat menjadi gambaran masyarakat Jakarta adalah aktivitas para pekerja dan transportasi yang penuh sesak, khususnya bus kota. Angkutan kota satu ini menjadi alat transportasi yang masih ditunggu dan dipenuhi penumpang, terutama pada waktu jam berangkat dan pulang kerja. Sesuatu hal yang biasa bagi masyarakat Jakarta menunggu angkutan umum dan berdesak-desakan dalam bus kota. Foto yang diambil pada 1993 di Jalan Sudirman, menunjukkan cahaya lampu kamera yang memantul kaca dan sekitarnya gelap sekaligus menampilkan kehidupan kota Jakarta yang masih dinamis meskipun malam mulai menjelang. Kegembiraan terlihat di wajah-wajah masyarakat Jakarta saat dipotret yang menunjukkan semangat yang masih ada meskipun pulang dari bekerja.

Moda transportasi lain yang digunakan oleh masyarakan kota Jakarta adalah kereta api.

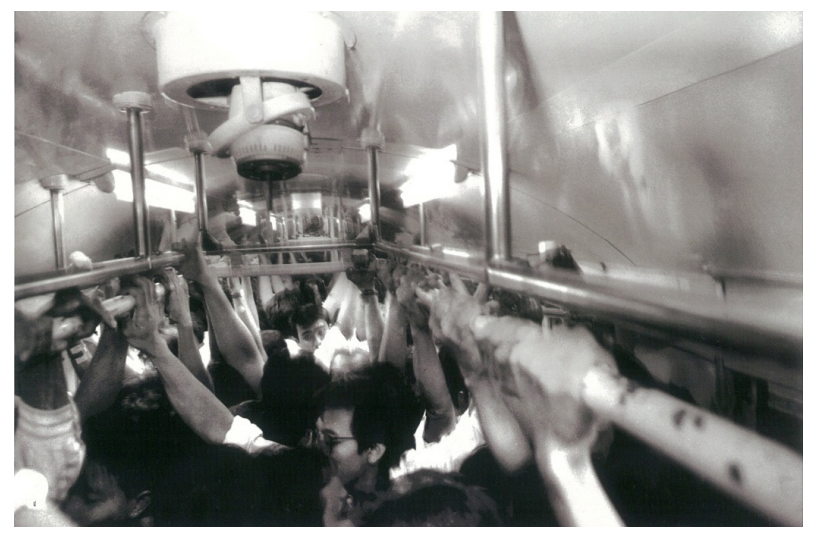

Gambar 5. Bergelantungan di dalam Jabodetabek jurusan Bogor, 1992 (Sumber: Prasetya 2011) 
Transportasi ini selalu penuh sesak karena menjadi pilihan untuk sampai tujuan dengan lebih cepat. Banyaknya tangan yang bergelantungan di pegangan atap lorong kereta api memperlihatkan penuhnya penumpang kereta. Lengan baju dan wajah yang tertampil dalam imaji cukup menunjukkan bahwa banyak di antara masyarakat Jakarta yang merupakan pekerja kantoran. Pakaian yang digulung rapi, tangan-tangan terlihat bersih dan halus, bukan tangan pekerja buruh kasar. Atribut jam tangan dan kacamata menambah kesan pekerja kantoran. Sama halnya dengan bus kota, dalam foto di dalam kereta api terdapat lampu yang menyala. Perjalanan kereta pada waktu malam dipadati penumpang menjadi ciri khas kehidupan Jakarta yang masih bergerak tanpa kenal waktu. Beberapa foto lain juga memperlihatkan para pekerja kantoran dengan jas rapi menunggu angkutan kota. Moda transportasi umum masih mencari penumpang meskipun lampu-lampu jalanan mulai menyala.

Selain itu, hampir semua foto yang tertampil mengandung unsur visual para pekerja atau

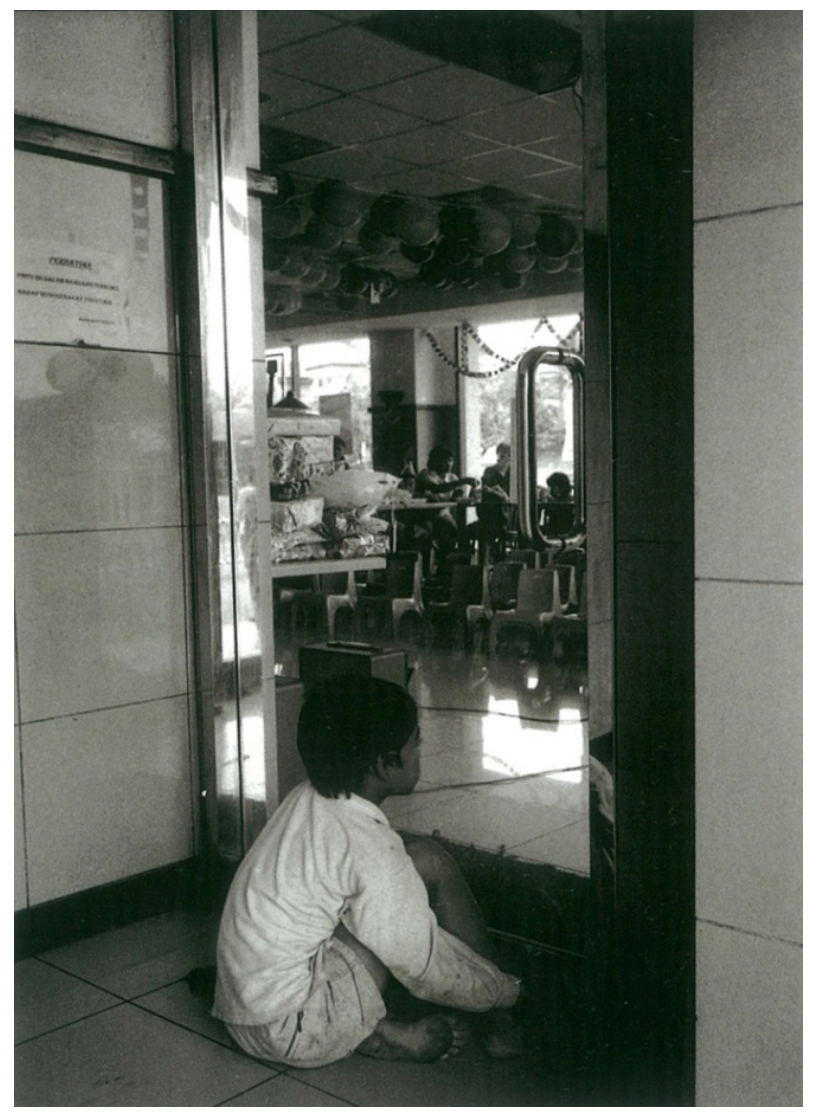

Gambar 6. McDonald's Bintaro, 1997

(Sumber: Prasetya 2011) memiliki unsur suatu pekerjaan tertentu. Jakarta seolah identik dengan kota para pekerja. Penuh sesaknya moda transportasi dengan para pekerja, selain merupakan imaji suatu peristiwa tertentu juga menyiratkan suatu profesi tertentu. Selama ini Jakarta sering menjadi tujuan pencari kerja karena banyaknya industri yang berkantor pusat di Jakarta dan sekitarnya. Fenomena ini berimplikasi pada bidang kehidupan yang lain pada masyarakat kota Jakarta, seperti tata kota, transportasi, hingga masalah sosial. Anak-anak yang bekerja, menjadi salah satu masalah sosial di Jakarta. Erik Prasetya dalam hal ini mengemasnya dalam cara yang "cantik" sehingga kesan pertama yang muncul adalah semangat kerja masyarakat Jakarta. Di sisi lain, terdapat foto yang menggambarkan keceriaan anak-anak saat bermain. Penggambaran visual tentang anak-anak Jakarta yang cukup kompleks, secara fisik maupun psikis.

Potret lain tentang Jakarta adalah tentang kemiskinan dan kesenjangan antara si kaya dan miskin. Objek yang diambil oleh Erik Prasetya untuk kemiskinan sekaligus kesenjangan adalah anak-anak. Di Jakarta, anak-anak yang seharusnya masih belajar di sekolah dasar atau menengah pertama tetapi kenyataannya anak-anak tersebut bekerja, dan menjadi hal yang mudah ditemui. Hal ini bisa dicontohkan seperti para ojek payung di musim hujan, anak-anak pencari kerang di Cilincing, hingga peminta-minta. Salah satu foto yang memperlihatkan kemiskinan sekaligus sejenjangan adalah foto seorang anak di balik pintu kaca McDonald. Pintu kaca memisahkan antara si miskin dan si kaya. Seorang anak dengan kaki

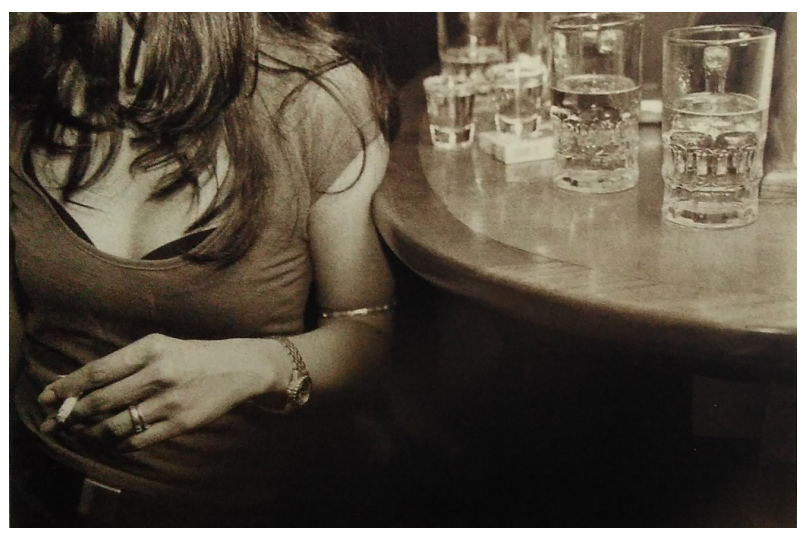

Gambar 7. Diskotek Bats, Shangrila Hotel, Oktober 1999 (Sumber: Prasetya 2011) 
kotor tanpa alas kaki, pakaian kotor, duduk di lantai sambil memandang ke dalam ruang berpintu kaca yang di dalam ruang tersebut terdapat orangorang yang sedang makan dengan ruang bersih, dan balon-balon yang menunjukkan adanya pesta. Dalam foto 6, anak tersebut tidak hanya memperlihatkan adanya kemiskinan yang ada di Jakarta, tetapi juga memperlihatkan adanya kesenjangan dalam masyarakatnya.

Kehidupan malam menjadi bagian yang tidak terpisahkan dari Jakarta. Sebagai kota besar, Jakarta seolah tidak tidur. Kehidupan malam dalam fotofoto karya Erik Prasetya tidak hanya orang-orang yang tetap bekerja meskipun pada waktu malam, tetapi juga kehidupan malam orang-orang yang menghabiskan waktu di kafe ataupun diskotek, baik dengan keluarga maupun teman. Orangorang tersebut menghabiskan malam dengan hiburan malam. Kehidupan yang cukup kontradiktif dengan kemiskinan yang ada di Jakarta, sekaligus mempertegas adanya kesenjangan di ibukota. Kehidupan malam identik dengan kemewahan yang menunjukkan gemerlapnya ibukota. Penampilan modis atau seksi, makanan minuman dengan harga di atas rata-rata umum, musik, minuman beralkohol, dan rokok menjadi objek yang mudah ditemui di kehidupan malam Jakarta. Orang-orang tersebut tidak akan bisa masuk ke klub atau tempat hiburan malam jika tidak memiliki uang yang cukup banyak. Secara visual setidaknya, selain pakaian, perhiasan dan aksesoris menjadi bagian yang tertampak dalam imaji, juga dapat menjadi indikator tingkat sosial ekonomi orang-orang tersebut dalam kehidupan malam.

Fotografi jalanan karya Erik Prasetya tentang Jakarta memang penggambaran kota ini dalam kurun waktu sebelum era pemerintahan sekarang, yang sudah mengalami era reformasi dan banyak perubahan. Akan tetapi, pada masa tersebut hal yang sering terdengar adalah Jakarta dengan penduduk padat, macet, kota tidak pernah tidur, banyak kemiskinan. Hal itu dapat tergambarkan dalam foto-foto tersebut. Masih kurang lebih sama seperti sekarang, Jakarta dengan kemacetan dan moda transportasi yang selalu penuh meskipun sudah ada perbaikan. Kemiskinan dan adanya kesenjangan yang masih belum hilang dari ibukota.

\section{Street Photography dan Keindahan}

Banyak ragam teknik pemotretan yang bisa digunakan dalam fotografi jalanan, antara lain snapshot photograhy, candid photography, straight photography, dan found objeck (objet's trouves) (Kusrini, 2015). Teknik secara umum digunakan dengan berbagai pertimbangan yang lebih berorientasi pada kemudahan praktis dan situasi serta kondisi lapangan di jalanan yang tidak memungkinkan untuk mengatur setting terlebih dahulu, baik itu menyangkut objek maupun kesempatan moment dan pencahayaan yang tepat. Masing-masing teknik dapat menghasilkan imaji dengan nilai estetikanya sendiri. Beberapa terminologi yang mencirikan nilai klasifikatoris karya-karya foto yang dikaitkan dengan teknik pemotretan ini, antara lain decesive moment, humant interest, press/journalistic photography, documentary, dan urban/city photography. Terminologi tersebut juga merupakan istilah genre dan nilai tematik dari sudut penampilan karya subjek fotografi.

Dalam pemahaman yang lain, fotografi jalanan merupakan produk dari interaksi antara seni fotografer dan ruang publik perkotaan. Hal ini dapat dibedakan dari fotografi dokumenter karena fotografer belum tentu termotivasi oleh nilai pembuktian atau fungsi sosial-politik foto yang dihasilkan. Berbeda juga dari foto jurnalistik, maka tujuan fotografi jalanan adalah mengekspresikan dan mengomunikasikan kesan subjektif dari pengalaman hidup sehari-hari di kota (http://www.oxfordartonline.com/diakses pada Jumat, 15 Januari 2016, pukul 15.09 WIB). Dalam praktiknya, street photography mengajarkan kejujuran. Di tengah kemajuan teknologi digital, street photography menjadi salah satu bagian dari fotografi yang benar-benar ingin menunjukkan siapa jati diri fotografer dengan menghasilkan foto-foto yang jujur dan apa adanya.

Foto-foto karya Erik Prasetya tidak berusaha menampilkan Jakarta secara indah karena menurutnya Jakarta memang tidak indah (Prasetya 2011). Melalui perspektif keindahan, maka foto jalanan dalam Jakarta: Estetika Banal berusaha menampilkan Jakarta seperti kehidupan sehari-hari yang biasa dilihat Erik Prasetya sebagai seorang fotografer. Erik tidak hanya melihat, namun juga 
menjadi bagian dari dalam kehidupan masyarakat. Menjadi bagian dari kehidupan Jakarta, menelusuri, dan merekamnya dalam karya foto. Seperti foto moda transportasi umum, Erik turut naik, menjadi penumpang bus kota, kereta api, dan menjadi bagian dari kehidupan malam. Keindahan dari foto-foto tersebut selain keindahan imaji yang menarik atau menyenangkan secara visual, tetapi juga teknik fotografi yang tidak biasa untuk suatu peristiwa atau objek tertentu. Misalnya action polisi yang sedang makan es krim atau ekspresi saat demo yang tidak terlihat "sangar", tetapi masih memperlihatkan sisi manusiawi mereka.

Berdasar atas segi teknik, secara sekilas fotofoto seperti diambil dengan cara cepat, namun jika dicermati, terdapat olah teknik fotografi yang dilakukan secara profesional sehingga secara visual memiliki makna. Sebagai contoh, dalam foto-foto yang diambil pada waktu malam hari dengan pencahayaan yang kurang, maka harus ada pengaturan teknik kamera yang tepat agar foto yang dihasilkan sesuai dengan keinginan. Selain itu, fotofoto dengan objek diam namun bisa menampilkan kesan dinamis, kondisi panas, kesedihan, semangat, kegembiraan, dan suasana yang kontradiktif tentu memerlukan pengaturan teknik yang tepat. Selain kelebihan teknik fotografi yang sesuai kondisi pada saat pemotretan, keindahan dari foto-foto karya Erik Prasetya terletak pada cerita yang disampaikan tentang Jakarta. Baik dari segi isi cerita tentang Jakarta maupun dari cara penyampaian visual yang kuat tentang Jakarta. Termasuk beberapa peristiwa besar yang terjadi di Jakarta menjadi bagian yang turut mewarnai cerita tentang kehidupan masyarakat Jakarta. Hal ini sekaligus menunjukkan bahwa fotografi jalanan memotret dari jalan ke jalan, bukan tentang kehidupan di jalanan. Fotografi jalanan adalah merekam perjalanan yang dilalui dalam bentuk imaji foto, baik itu perjalanan kehidupan maupun kehidupan atau segala sesuatu yang ada di sepanjang jalan secara fisik.

\section{Simpulan}

Fotografi jalanan tentang Jakarta yang dibukukan Erik Prasetya dalam Jakarta: Estetika Banal merupakan foto-foto karyanya selama bertahun-tahun. Hal ini tentu bukan foto yang asal memotret atau asal jepret saat berada di jalan kemudian dibukukan. Berbagai peristiwa yang terekam foto-foto tersebut menampilkan cerita tentang Jakarta pada masa 1990-2000'an secara lengkap. Bukan hanya peristiwa besar atau yang diberitakan oleh media massa, tetapi juga peristiwa sehari-hari yang ditemuinya dan dilalui sebagai bagian dari warga Jakarta. Erik Prasetya berhasil membingkai Jakarta dalam cerita tentang sebuah kota yang "indah" atau "menyenangkan" dalam versinya. Kesenangan dan kebahagiaan tidak selalu tentang tawa, meskipun terdapat foto orangorang yang sedang tertawa, kesemrawutan jalanan tidak selalu harus ditanggapi dengan kekesalan. Cerita tentang kota Jakarta yang dinamis adalah seperti kota-kota yang lain, hanya saja pergerakan masyarakatnya lebih dinamis dan cepat.

Foto-foto karya Erik Prasetya juga memberikan pengertian fotografi jalanan yang lebih luas, bahwa genre ini tidak hanya merekam peristiwa yang ada di jalanan atau jalan secara fisik dengan gedung dan aspal ataupun beton, tetapi juga perjalanan kehidupan yang dilalui, menelusuri kehidupan dari berbagai sisi dengan pergerakan yang ada di dalamnya. Di sepanjang jalan, baik jalan besar maupun kecil, juga gang sempit, terdapat kehidupan masyarakat yang dinamis. Fotografi jalanan bukan sekadar datang dan memotret, namun harus ada pemahaman tentang objek tersebut sehingga tahu kapan saat (moment) yang tepat sehingga didapatkan sebuah cerita yang dapat tersaji secara visual.

\section{Ucapan Terima Kasih}

Penulis mengucapkan terima kasih kepada Lembaga Penelitian Institut Seni Indonesia Yogyakarta yang telah menyediakan dana penelitian yang memungkinkan artikel ini bisa terwujud.

\section{Kepustakaan}

Abdi, Y., 2011. Photography From My Eyes: Semua Hal Yang Perlu Anda Ketahui untuk Menjadi Fotografer Serba Bisa. Jakarta: Kompas Gramedia. 
Clarke, G., 1997. The Photograph. Oxford: Oxford University Press.

Kusrini. 2015. "Potret Diri Digital dalam Seni dan Budaya Visual". Journal of Urban Society's Arts, 2(2), 111-122. doi:http://dx.doi. org/10.24821/jousa.v2i2.1448

Prasetya, E., 2011. Jakarta: Estetika Banal. Jakarta:
KPG.

Soedjono, S., 2006. Pot-Pourri Fotografi. Jakarta: Universitas Trisakti.

Soedjono, S. 2015. "Creative by Way of Adaption: Ramayana Relief of Prambanan Temple". Journal of Urban Society's Arts, 2(2), 104-110. doi:http:// dx.doi.org/10.24821/jousa.v2i2.1447 